\title{
Regulated expression of functional external guide sequences in mammalian cells using a U6 RNA polymerase III promoter
}

\author{
ELIZAVETA KOVRIGINA, LI YANG, EMMANUEL PFUND, and SIDNEY ALTMAN \\ Department of Molecular, Cellular and Developmental Biology, Yale University, New Haven, Connecticut 06520, USA
}

\begin{abstract}
A regulatable promoter has been stably integrated into a human embryonic kidney cell line. The promoter is a pol III mouse promoter and is under the control of ponasterone $A$, an ecdysone inducer. The promoter controls transcription of an external guide sequence (EGS) targeted against Rpp38, a protein subunit of human RNase $P$, or of lamin $A / C$, a gene product located in the nucleus. The amounts of protein of both gene products are severely reduced when the EGSs are made. Several other, but not all, of the protein subunits of RNase $P$ are also inhibited in both mRNA and protein levels when Rpp38 mRNA is targeted.
\end{abstract}

Keywords: RNase P; Rpp38; lamin A/C; inhibition of gene expression

\section{INTRODUCTION}

RNA technologies provide a promising gene-targeting approach for use in basic research and clinical therapeutic applications. One of the gene-targeting agents makes use of an external guide sequence (EGS), a small oligonucleotide guide sequence that targets the mRNA for degradation by RNase P (Yuan and Altman 1994). Targeting with an EGS results in irreversible cleavage of the target RNA in a catalytic fashion, while the EGS can be recycled. This targeting approach uses the ubiquitous endogenous RNase $\mathrm{P}$ for degradation of the target mRNA (Forster and Altman 1990; Yuan et al. 1992; Plehn-Dujowich and Altman 1998).

Earlier, we designed an EGS that binds to the mRNA of Rpp38, one of the RNase P protein subunits, and forms a complex resembling the structure of a tRNA, and directs human RNase P to cleave the target mRNA (Kovrigina et al. 2003). This EGS (EGS ${ }^{\text {Rpp38}}$ ) showed exquisite specificity and directed the RNase P-dependent cleavage at the targeted location within Rpp38 mRNA. The successful function of EGS ${ }^{\text {Rpp38 }}$ has been illustrated by a decrease of Rpp38 gene expression in HeLa cells in tissue culture. Some, but not

Reprint requests to: Sidney Altman, Department of Molecular, Cellular and Developmental Biology, Yale University, New Haven, Connecticut 06520, USA; e-mail: sidney.altman@yale.edu; fax: (203) 432-5713.

Article published online ahead of print. Article and publication date are at http://www.rnajournal.org/cgi/doi/10. 1261/rna.2140505. all, of the other RNase $\mathrm{P}$ protein subunits were also inhibited as a consequence of the EGS ${ }^{\mathrm{Rpp} 38}$-targeting activity and the ensuing low level of Rpp38. The nature of this coordinate inhibition of gene expression is not yet understood. EGS ${ }^{\mathrm{Rpp} 38}$ was expressed transiently from a plasmid and its production was unregulated in all of those experiments (Kovrigina et al. 2003). We also showed that lamin A/C was also decreased in gene expression by the expression of $\mathrm{EGS}^{\mathrm{Rpp} 38}$, another aspect of down-regulation that remains to be understood.

Here we report the development and properties of an inducible, stably integrated vector that permits control of the expression of EGS in tissue culture. To assess the intracellular regulation of this U6 promoter-driven EGS, the $\mathrm{EGS}^{\mathrm{Rpp} 38}$-expressing stable cell line, based on the human EcR 293 cell line (Invitrogen), was established to serve as a host for EGS ${ }^{\mathrm{Rpp} 38}$. The expression of EGS ${ }^{\mathrm{Rpp} 38}$, which is induced by addition of ponasterone $\mathrm{A}$, led to a dramatic decrease of target Rpp38 mRNA and Rpp38 protein levels. The same pattern of gene expression in the cell line, as in transiently transfected HeLa cells, was observed. Ponasterone A-dependent $\mathrm{EGS}^{\mathrm{Rpp} 38}$ induction led to significant reduction of RNase $\mathrm{P}$ holoenzyme enzymatic activity. In addition, we also looked at an EGS to lamin A/C to see whether it could be down-regulated by the inducer promoter. In fact, lamin A/C was down-regulated, but its effects in response to a specific EGS were different from that of Rpp38. 


\section{RESULTS}

\section{Strategy for generation of an inducible EGS-expressing cell line}

An inducible system, used for regulated expression of proteins, was modified to develop a system for regulated EGS production in tissue culture. Two systems, tetracycline- and ecdysone-inducible, which allow transcription only upon addition of the corresponding inducer (see Materials and Methods and the Invitrogen catalog), are widely used and well-characterized (Shockett et al. 1995; No et al. 1996). We selected an ecdysone-inducible expression system to provide regulated production of EGS. The system is based on the ability of an ecdysone analog, ponasterone $\mathrm{A}$, to activate transcription in mammalian cells (Yao et al. 1993).

To create a regulated EGS-expressing vector, pEcU6EGS, we used a U6 promoter, which can directly transcribe small RNAs (No et al. 1996), such as an EGS, and subsequently to form EGS-targeted RNA duplexes directly in the cell nucleus. To achieve regulation from this promoter at the level of transcription, the HSP promoter and the multiple cloning site of pIND (Invitrogen) vector were replaced with the U6 promoter and a multiple cloning site from the pmU6 plasmid (see Materials and Methods). The new multiple cloning site contains unique restriction sites, suitable for use based on the strategy of EGS design developed in our laboratory previously. According to this strategy, PstI and KpnI restriction sites were used to make pEcU6$\mathrm{EGS}^{\mathrm{Rpp} 38}$ and pEcU6-EGS ${ }^{\mathrm{Rpp} 38}$-TL constructs, which express EGS $^{\text {Rpp38 }}$ (Kovrigina et al. 2003) and EGS ${ }^{\text {Rpp38 }}$-TL, accordingly. A similar strategy was used to make EGSs for lamin $\mathrm{A} / \mathrm{C}$ that were also controlled by the inducible promoter (see Materials and Methods).

To generate inducible EGS ${ }^{\mathrm{Rpp} 38}$ and $\mathrm{EGS}^{\mathrm{Rpp} 38}$-TL expressing cell lines, we used the zeocin-resistant EcR 293 cell line (Invitrogen), which stably express the VgEcR and RXR receptor subunits (Yao et al. 1993). Cells were transfected with pEcU6-EGS ${ }^{\mathrm{Rpp} 38}$ and pEcU6-EGS ${ }^{\mathrm{Rpp} 38}{ }_{-\mathrm{TL}}$ and selected for neomycin resistance. Neomycin-resistant EcR 293 clones were screened for the presence of the $\mathrm{EGS}^{\mathrm{Rpp} 38}$ and $\mathrm{EGS}^{\mathrm{Rpp} 38}$-TL sequences and neomycin (as a control) by assaying with reverse-transcription enzymatic activity as described in Materials and Methods. Because the presence of the desired sequences in the cell does not provide direct evidence of an individual clone's ability to produce functional EGS, clones with the highest level of transcription of the EGS genes as assayed by RT activity were chosen for further testing. These clones were grown in the absence and presence of ponasterone $\mathrm{A}(5 \mu \mathrm{M})$ for $48 \mathrm{~h}$, and their ability to produce EGS was tested by Northern hybridization of total RNA extracted from each of the isolated clones. Oligonucleotide probes corresponding to $\mathrm{EGS}^{\mathrm{Rpp} 38}$ and $\mathrm{EGS}^{\mathrm{Rpp} 38}$-TL were used for diagnosis. Additionally, we examined total protein lysates, prepared from the clones that produce $\mathrm{EGS}^{\mathrm{Rpp} 38}$, for the ability to down-regulate the amount of Rpp38 protein. Finally, one clone with the highest level of EGS production (for $\mathrm{EGS}^{\mathrm{Rpp} 38}$ and $\mathrm{EGS}^{\mathrm{Rpp} 38}$-TL) and most severe decrease in Rpp38 protein level (for EGS ${ }^{\mathrm{Rpp} 38}$ only) was chosen as a working clone.

\section{Inducible expression of functional EGS ${ }^{\mathrm{Rpp} 38}$ in EcU6-EGS ${ }^{\mathrm{Rpp} 38}$ cells}

We examined the ability of EcU6-EGS ${ }^{\text {Rpp38 }}$ cells of a working clone to produce active $\mathrm{EGS}^{\mathrm{Rpp} 38}$ after induction with ponasterone A. For this purpose, cells $\left(2.2 \times 10^{6}\right)$ were seeded onto a plate and $10-\mathrm{cm}$ separate such dishes were grown for $24 \mathrm{~h}$. Ponasterone A $(5 \mu \mathrm{M})$ was added and cells were collected on the first, second, fourth, eighth, and tenth day after induction. Twenty clones were chosen and examined for the ability to grow slowly in the presence of ponasterone A. One clone was chosen for further study at this time.

To study the induction reversibility, cells were grown in the presence of ponasterone A for $10 \mathrm{~d}$, then washed with PBS; fresh medium without inducer was added, and the cells were grown for an additional $2 \mathrm{~d}$. Control cells were grown in the absence of ponasterone A. Cells were collected at indicated time points (Fig. 1) and divided into two parts. One part was used to prepare protein samples, the other part was used for total RNA extraction. Total RNA was separated on a $2.5 \%$ agarose gel and probed with radioactive oligonucleotides complementary to $\mathrm{EGS}^{\mathrm{Rpp} 38}, \mathrm{H} 1 \mathrm{RNA}$, and ribosomal $5 \mathrm{~S}$ RNA. As shown on Figure 1A (top), detectable amounts of EGS $^{\mathrm{Rpp} 38}$ RNA appeared on the first day $(24 \mathrm{~h})$ after induction (lanes 3,4), and stays approximately at the same level until the tenth day (lanes 5-8). The EGS ${ }^{\mathrm{Rpp} 38}$ signal disappeared from cells after $2 \mathrm{~d}$ of growth in the absence of inducer (lane 9). Control cells also showed no visible presence of $\mathrm{EGS}^{\mathrm{Rpp} 38}$ RNA (lane 3). The position corresponding to $\mathrm{EGS}^{\mathrm{Rpp} 38}$ on the agarose gel was defined using EGS ${ }^{\mathrm{Rpp} 38}$ transcribed in vitro (lanes 1,2). The amount of ribosomal $5 \mathrm{~S}$ RNA (Fig. 1A, bottom) and H1 RNA (data not shown) did not change during those $10 \mathrm{~d}$ of cell growth in the presence of ponasterone A. Inducible expression of $\mathrm{EGS}^{\mathrm{Rpp} 38} \mathrm{RNA}$ in tissue culture decreases the amount of target Rpp38 mRNA and protein specifically (see below) and does not influence $5 \mathrm{~S}$ and H1 RNA (data not shown). This last result with H1 RNA replicates an earlier finding on this system in transfection experiments (Kovrigina et al. 2003).

\section{Does EGS $S^{\mathrm{Rpp38}}$ expression down-regulate Rpp38 mRNA and protein levels in vivo?}

Total RNA $(5 \mu \mathrm{g})$ from each sample was used in a reversetranscription reaction with random primers. cDNA samples were used as a templates in the PCR reaction with specific primers to Rpp38 and actin mRNAs. The data show that the amount of Rpp38 mRNA was decreased in the cells after 

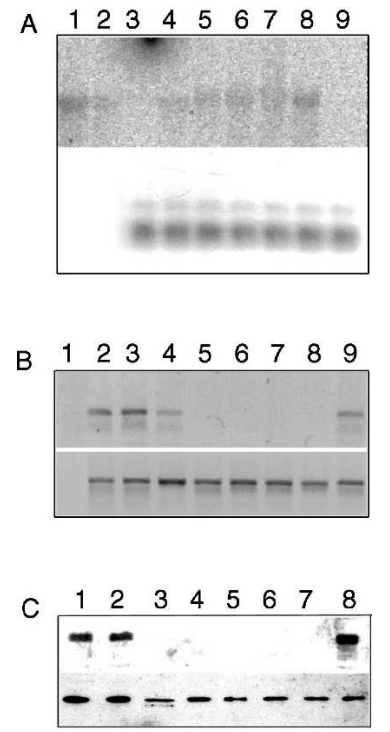

FIGURE 1. Inducible expression of $\mathrm{EGS}^{\mathrm{Rpp} 38}$ leads to the reduction of Rpp38 mRNA and protein level in vivo. Samples of cells, harboring pEcU6-EGS ${ }^{\mathrm{Rpp} 38}$, were grown for $0 \mathrm{~d}$ (lane 3), $2 \mathrm{~d}$ (lane 4), $4 \mathrm{~d}$ (lane 5), $6 \mathrm{~d}$ (lane 6), $8 \mathrm{~d}$ (lane 7), and $10 \mathrm{~d}$ (lane 8 ) after induction with ponasterone A $(5 \mu \mathrm{M})$. One sample (lane 9) was grown for $10 \mathrm{~d}$ in the presence of ponasterone $\mathrm{A}$, and then $2 \mathrm{~d}$ in the absence of inducer. Cell samples were harvested and divided into two parts for total RNA extraction and total protein preparation. $(A)$ Northern blot analysis. Total RNA $(10 \mu \mathrm{g})$ were hybridized with end-labeled oligonucleotide that corresponded to $\mathrm{EGS}^{\mathrm{Rpp} 38}$ (top) or 5S (bottom) RNA. Control: 0.1 pmol (lane 1) and $0.01 \mathrm{pmol}$ (lane 2) of in vitro-transcribed EGS $\mathrm{Rpp}^{\mathrm{R} 38}$ RNA. (B) RT-PCR analysis. Total RNA $(5 \mu \mathrm{g})$ were processed as described in Materials and Methods. Control: no cDNA (lane 1), Rpp38 (lane 2, top), or actin (lane 2, bottom) cDNA was added as a template. $(C)$ Western blot analysis. Samples of total protein were prepared from pEcU6-EGS ${ }^{\mathrm{Rpp} 38}$ cells, growing for $0 \mathrm{~d}$ (lane 2), $2 \mathrm{~d}$ (lane 3), $4 \mathrm{~d}$ (lane 4), $6 \mathrm{~d}$ (lane 5), $8 \mathrm{~d}$ (lane 6), and $10 \mathrm{~d}$ (lane 7) in the presence of ponasterone $\mathrm{A}$; cells grown for $10 \mathrm{~d}$ in the presence and $2 \mathrm{~d}$ in the absence of ponasterone A (lane 8). Cells harboring pEcU6$\mathrm{EGS}^{\mathrm{Rpp} 38}$-TL were grown for $10 \mathrm{~d}$ in the presence of ponasterone $\mathrm{A}$ as a control (lane 1). Samples $(10 \mu \mathrm{g})$ were separated in a $12.5 \%$ polyacrylamide/SDS gel, transferred to nitrocellulose filter, and immunoblotted with polyclonal antibodies against the Rpp38 (1:100 dilution) and $\gamma$-actin (1:5000 dilution).

addition of ponasterone A (Fig. 1B, lanes 4-8) and recovered to the level comparable in control cells (lanes 3,9) $2 \mathrm{~d}$ after removal of ponasterone A. The amounts of EGS (none) and Rpp38 were at the usual normal amounts. The amounts of actin RNA were nearly equal in all samples (Fig. 1B, bottom). H1 RNA, transcribed by pol III, was also not affected by EGS ${ }^{\text {Rpp38 }}$.

To study the EGS ${ }^{\mathrm{Rpp} 38}$ effect on protein expression, cell extracts $(10 \mu \mathrm{g})$ were separated on a SDS/polyacrylamide gel, transferred to a nitrocellulose membrane, and blotted with polyclonal antibodies against Rpp38 or monoclonal antibodies against $\gamma$-actin (Fig. 1C). The data indicate that the amount of Rpp38 protein was not changed significantly during the first day after induction (Fig. 1C, top, lanes 1,2), but greatly decreased on the second day ( $48 \mathrm{~h}$; Fig. 1C, top, lane 3). Rpp38 protein level was down-regulated, as inducer was present in the cell medium (Fig. 1C, top, lanes 4-7) and restored to the control level on the second day of cell growth without inducer in the medium (Fig 1C, top, lane 8). The amount of actin did not change after induction (Fig. $1 \mathrm{~B}$, bottom). A time course is shown in a kinetic fashion in Figure 2.

We conclude that expression of EGS ${ }^{\mathrm{Rpp} 38}$ led to specific down-regulation of Rpp38 mRNA and protein amounts in tissue culture. There were no nonspecific effects of the foreign RNA in cells. Additionally, the stable cell line, established to serve as a host for EGS ${ }^{\mathrm{Rpp} 38}$-TL, was shown to produce $\mathrm{EGS}^{\mathrm{Rpp} 38}$-TL in vivo. Mutants in the T-loop in EGSs, the equivalent of the T-loop in tRNA, prevent function of RNase P in attacking EGS-target RNA complexes and thereby are controls for the effects of EGSs as shown earlier (Plehn-Dujowich and Altman 1998). We found that expression of $\mathrm{EGS}^{\mathrm{Rpp} 38}$-TL did not change Rpp38 mRNA and protein amounts (data not shown).

The effect of EGS ${ }^{\mathrm{Rpp} 38}$ production on the expression of other RNase P protein subunits was examined. Total RNA was extracted from EcU6-EGS ${ }^{\mathrm{Rpp} 38}$ cells before and after induction, and radioactive-labeled cDNA samples were obtained (see Materials and Methods). These samples were probed with the DNA for all RNase P protein subunit genes and DNA for actin (as a control), and the signal for noninduced and induced cDNA probes were quantified. The data, shown in Table 1, indicate that the amounts of mRNA of other RNase P protein subunits, such as Rpp21, Rpp25, hPop5, Rpp29, and hPop1 were decreased in cells that expressed EGS ${ }^{\mathrm{Rpp} 38}$. Rpp14, Rpp20, Rpp30, and Rpp40 did not change significantly. These results are in agreement with our data obtained for HeLa cells, which expressed EGS ${ }^{\mathrm{Rpp} 38}$ after transient transfection (Kovrigina et al. 2003).

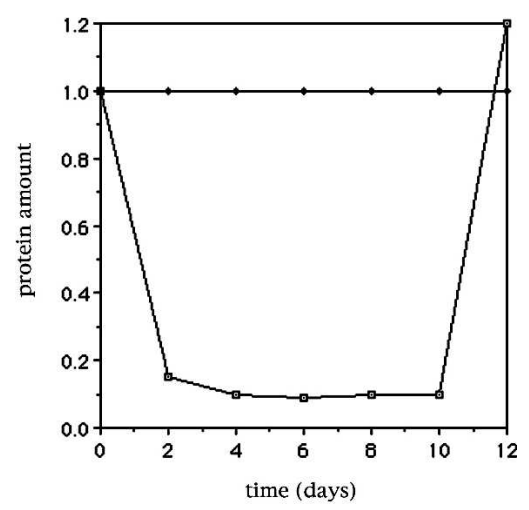

FIGURE 2. Kinetics of inhibition of expression of Rpp38 after induction of $\mathrm{EGS}^{\mathrm{Rpp} 38}$. The kinetics of the amount of protein of Rpp38 after induction of the EGS ${ }^{\mathrm{Rpp} 38}$ gene by ponasterone A. Proteins were measured by Western blots. Actin $(\downarrow)$; Rpp38 $(\square)$. This experiment was repeated several times with essentially the same result. 
TABLE 1. Expression level of RNase P protein subunits after EGS ${ }^{R p p 38}$ induction

\begin{tabular}{lcc}
\hline Gene product & cDNA & Protein \\
\hline actin & 1.0 & 1.0 \\
Rpp14 & 1.0 & - \\
Rpp20 & 0.5 & 1.2 \\
Rpp21 & 0.1 & 0.4 \\
Rpp25 & 0.1 & 0.4 \\
Rpp29 & 0.5 & 0.4 \\
Rpp30 & 1.0 & 1.0 \\
Rpp38 & 0.1 & 0.3 \\
Rpp40 & 0.8 & 1.0 \\
hPop5 & 0.2 & - \\
hPop1 & 0.5 & 0.1 \\
lamin A & - & \\
\hline
\end{tabular}

cDNA corresponding to Rpp14, Rpp20, Rpp21, Rpp25, Rpp29, Rpp30, Rpp38, Rpp40, hPop1, hPop5, and actin were dotted on nitrocellulose filters, cross-linked with Stratalinker (Stratagene), and hybridized with labeled cDNA probe. To obtain the labeled cDNA probe, one 100-mm plate of pEcU6-EGS Rpp38 cells was harvested before and $48 \mathrm{~h}$ after induction. Total RNA, purified from cells, was used in the reverse transcription reaction. CDNA was labeled with $\left.{ }^{32} \mathrm{P}\right] \mathrm{dCTP}$ and results were then quantified (see Materials and Methods). The results were normalized to controls. A difference of $>0.2$ lower than the control was regarded as reliably significant. For Western blots, the instensity of bands staining with antibodies was measured from films of the gels. Actin, which was the control, was normalized in each slot to a value of one, and the other bands were then normalized to the level of actin. These results are from one experimental value, but the experiments were repeated, in part, several times with the same result.

\section{Expression of lamin A/C protein after targeting by EGSs in stable cells}

As we have shown previously (Kovrigina et al. 2003), lamin $\mathrm{A} / \mathrm{C}$ is also down-regulated in terms of its protein production by $\mathrm{EGS}^{\mathrm{Rpp} 38}$. In the case of the inducible promoter, the same result is clear (Table 1 and below). Endogenous protein expressions were measured for 24 and $48 \mathrm{~h}$ after transiently transfected with control pmU6, pmU6-EGS ${ }^{114}$, or pmU6$\mathrm{EGS}^{144}$. Compared with control cells, which were transfected with pmU6, both $\mathrm{EGS}^{114}$ and EGS ${ }^{144}$, EGSs for lamin A/C, showed about $60 \%$ reduction of the endogenous expression of lamin for $48 \mathrm{~h}$ after transient transfection (data not shown). Each kind of protein expression in control cells was individually set as 1 , and the relative ratios of each kind of protein expression were compared with actin.

Stable cells that could express EGSs against lamin A/C were induced with $5 \mu \mathrm{M}$ of ponasterone $\mathrm{A}$ to produce $\mathrm{EGS}^{144}$ and sampled for several time points. As shown in Table 2, after 48-h induction, EGS ${ }^{144}$ effected about a $70 \%$ reduction on the endogenous expression of lamin $\mathrm{A} / \mathrm{C}$, but a lesser result for 24-h induction. On the other hand, no clear reduction of RNase $\mathrm{P}$ protein subunits was found (including Rpp21, Rpp25, Rpp29, Rpp30, Rpp38, Rpp40, and Pop1). The results for 4 or $6 \mathrm{~d}$ after induction are consistent with the results for $2 \mathrm{~d}$.
Each kind of protein expression in control cells was individually set as 1 , and the relative ratios of each kind of protein expression, compared with actin, were demonstrated on the right panel of Table 2. In these experiments, lamin $\mathrm{A} / \mathrm{C}$ was decreased in expression as measured by Western blots. However, no RNase P protein subunits are downregulated when $\mathrm{EGS}^{144}$ (lamin A/C) is used as the effective agent (Table 2). This result indicates that there is a two-way regulation pathway for lamin A/C (see Discussion).

\section{Production of $\mathrm{EGS}^{\mathrm{Rpp} 38}$ in cells in tissue culture leads to the reduction of RNase $P$ enzymatic activity}

To study the effect of EGS ${ }^{\mathrm{Rpp} 38}$ on RNase P enzymatic activity, samples of an S16 extract were prepared from cells grown for $48 \mathrm{~h}$ in the absence or presence of ponasterone A. For RNase P activity assays, aliquots (equal total amounts of protein) were mixed with radioactive-labeled substrate. The reaction mixtures were incubated for $1,2,4,8$, and 16 min at $37^{\circ} \mathrm{C}$ and terminated by addition of an equal volume $(10 \mu \mathrm{L})$ of $40 \mathrm{mM}$ EDTA/8 $\mathrm{M}$ urea. As shown in Figure 3A, RNase P in the S16 from the extract of noninduced cells was capable of cleaving substrate completely after 4 min of reaction (lane 4); cleaved $5^{\prime}$ - and $3^{\prime}$-products of substrate appeared after $1 \mathrm{~min}$ of reaction (lane 2). When S16 RNase P from the extract of induced cells was added to labeled substrate, traces of the $3^{\prime}$ tRNA cleavage product appeared only at $8 \mathrm{~min}$ of reaction (Fig. 3A, lane 11). To compare activity of RNase P from noninduced and induced extracts, time curves of RNase $\mathrm{P}$ activity were calculated based on the total amount of precursor tRNA cleaved in the course of the reaction. Figure

TABLE 2. Expression of EGS against lamin A/C leads to the reduction of lamin $\mathrm{A} / \mathrm{C}$ expression, but not RNase $\mathrm{P}$ protein subunits

\begin{tabular}{lccccc}
\hline & \multicolumn{7}{c}{ Time after } & \multicolumn{5}{c}{ ponasterone induction (hr) } & \\
Protein & 0 & 24 & 48 & 96 & 144 \\
\hline lamin A/C & 1 & 0.79 & 0.26 & 0.35 & 0.31 \\
Rpp21 & 1 & 0.73 & 0.88 & & \\
Rpp25 & 1 & 0.87 & 0.80 & & \\
Rpp29 & 1 & 1.02 & 0.84 & & \\
Rpp30 & 1 & 0.90 & 0.66 & 0.89 & 0.89 \\
Rpp38 & 1 & 1.18 & 0.85 & 1.0 & 0.8 \\
Rpp40 & 1 & 0.94 & 0.83 & 0.92 & 0.87 \\
hpop1 & 1 & 0.86 & 0.80 & & \\
\hline
\end{tabular}

Western blots were performed as described in Materials and Methods. Each kind of protein expression in control cells (not induced) was individually set as 1 , and the relative ratios of each kind of protein expression, compared with actin, are shown in the numbers. After transfection for $24 \mathrm{~h}$, EcR 293 cells were plated at a 1:10 or higher dilution into fresh growth medium with $500 \mu \mathrm{g} / \mathrm{mL}$ Geneticin. Samples of total protein were prepared from stable cells induced by adding $5 \mu \mathrm{M}$ ponasterone A (Invitrogen) for 24 and $48 \mathrm{~h}$. Two separate measurements were taken of lamin A/C, Rpp30, Rpp38, and Rpp40. The other data are from single measurements. 
A

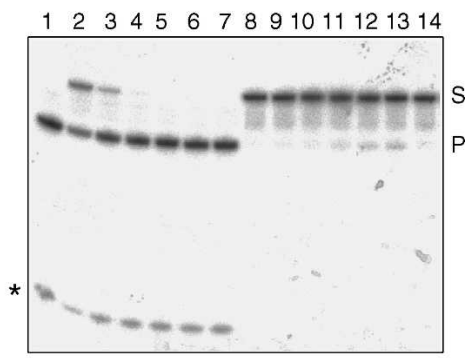

B

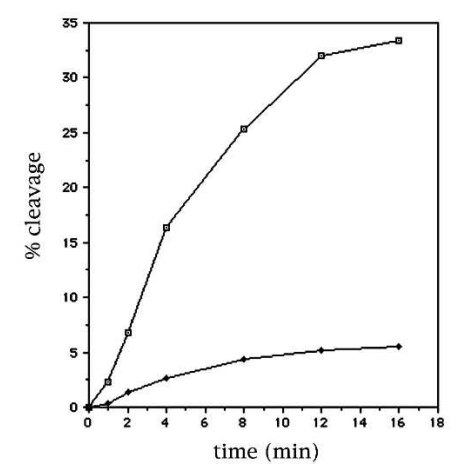

FIGURE 3. Inhibition of RNase $P$ activity after induction of $E G S^{\text {Rpp } 38}$ in tissue culture. Cells producing EGS ${ }^{\mathrm{Rp} 38}$ were harvested before induction or $48 \mathrm{~h}$ after induction. S16 extracts, prepared from these cells, were tested for RNase P activity in vitro (lanes 2-7, before induction; lanes 8-13, after induction; see Materials and Methods). (A) Aliquots were taken from the reaction mixture after addition of substrate at $1 \mathrm{~min}$ (lanes 2,8), 2 min (lanes 3,9), 4 min (lanes 4,10), 8 min (lanes 5,11), 12 min (lanes 6,12), and 16 min (lanes 7,13), and the products of the reaction were separated by electrophoresis in an $8 \%$ polyacrylamide gel that contained $7 \mathrm{M}$ urea. Controls: purified RNase P (lane 1) or no RNase P (lane 14) was added. (S) Substrate; (P) tRNA-containing product. The $5^{\prime}$ leader portion of the product runs near the bottom of the gel. $(B)$ The amount of cleavage was determined using a PhosphorImager. Activity is expressed as the percentage of total substrate that was cleaved. Measurements of the extent of cleavage were restricted to the linear range of product formation. No inducer $(\square)$; with inducer $(\bullet)$.

3B shows that RNase $\mathrm{P}$ activity of cells which expressed $\mathrm{EGS}^{\mathrm{Rpp} 38}$ in the presence of inducer was inhibited more than sevenfold compared with the control cells.

\section{Populations of cells harboring an EGS exhibit different efficacy for ecdysone-regulated gene expression}

We note that cells after induction with ponasterone A grow approximately two to three times slower than noninduced control cells. To study this effect, EGS ${ }^{\mathrm{Rpp} 38}$-producing cells were plated onto two $10-\mathrm{cm}$ dishes at a very low $(<5 \%$ confluence) density to ensure that each colony was well separated and originated from a single cell. One plate contained medium with ponasterone $\mathrm{A}(5 \mu \mathrm{M})$, another plate (control) contained medium without addition of ponasterone A. The colonies from both plates were examined after 5 $\mathrm{d}$ of growth, and the number of cells in each colony was counted in five independent repeats. Table 3 presents results of the amount of cells in each colony as an average number.

The data shows that there are two portions of cells within the cell line as follows: one portion, which died or dramatically slowed growth after induction, and a second much smaller portion, the rate of growth of which did not change after induction. Such a difference in growth rates among cells within one cell population could be due to a number of variables, including irregularity in ecdysone-controlled gene expression among cells within the particular cell line.

\section{DISCUSSION}

A cell line with a stable, inducible U6 promoter was constructed in order to directly regulate the production of an EGS against Rpp38, one of the protein subunits of human cell RNase P. The line was constructed from a commercially available plasmid (Invitrogen) that had a pol II promoter under the control of an ecdysone regulatable system. We replaced the pol II promoter with a pol III promoter, mU6, to enhance the production of an EGS cloned under its control. The methods used are well described in the literature and in the manufacturer's instructions.

The time required from the addition of the inducer, ponasterone $\mathrm{A}$, to observe a $\mathrm{EGS}^{\mathrm{Rpp} 38}$-mediated reduction in both the mRNA and protein of Rpp38 was $24 \mathrm{~h}$. As was the case for transient transfection using this EGS, other protein subunits of RNase $\mathrm{P}$ were also inhibited in expression but about half of the subunits were not, as reported earlier (Kovrigina et al. 2003). This latter result was also observed in EGS targeting of some of the protein subunits that were down-regulated in expression. The reason for this peculiar control of gene expression is not yet clear, but the stable inducible regulation of the transcription of the EGS is a valuable new technique. However, there was a clear difference in related experiments with lamin $\mathrm{A} / \mathrm{C}$.

The protein lamin A/C, a nuclear protein, was also observed to be decreased in expression with an EGS directed against Rpp38 (Table 1; Kovrigina et al. 2003). The presumption was that lamin $\mathrm{A} / \mathrm{C}$ and the RNase $\mathrm{P}$ protein subunits were inter-

\begin{tabular}{lcc} 
TABLE 3. Influence of $\mathrm{EGS}^{\mathrm{Rpp} 38}$ production on cell growth \\
\hline $\begin{array}{l}\text { Number of cells } \\
\text { in each colony }\end{array}$ & $\begin{array}{c}\text { in the } \\
\text { presence of } \\
\text { inducer }\end{array}$ & $\begin{array}{r}\% \text { in the } \\
\text { absence } \\
\text { of inducer }\end{array}$ \\
\hline 0 (no growth) & 45 & 0 \\
$1-25$ & 45 & 0 \\
$25-50$ & 5 & 32 \\
$50-100$ & 5 & 45 \\
$100-$ more & 0 & 23 \\
\hline
\end{tabular}

Cells $\left(2.2 \times 10^{5}\right)$ producing $\mathrm{EGS}^{\mathrm{Rpp} 38}$ and $\mathrm{EGS}^{\mathrm{Rpp} 38}$-TL were plated in separate $10-\mathrm{cm}$ tissue culture dishes and grown in the presence of the inducer, ponasterone $\mathrm{A}$, for $4 \mathrm{~d}$ and the number of cells in each colony was counted. The numbers represent the cell count average from five independent experiments. Twenty colonies were counted for each number in the table. 
related in function inside the nucleus, perhaps during cell division. However, a stable cell line that expressed an EGS targeting lamin $\mathrm{A} / \mathrm{C}, \mathrm{EGS}^{144}$, showed, as expected, a decrease in the expression of lamin $\mathrm{A} / \mathrm{C}$, but showed no signs of downregulation of several other RNase $\mathrm{P}$ subunits, including the ones usually down-regulated when, for example, Rpp38 was attacked with an EGS. Clearly, there is a two-way process involved in expression of lamin $\mathrm{A} / \mathrm{C}$; first, it is down-regulated when one of the susceptible RNase $\mathrm{P}$ protein subunits is attacked; and second, it alone is decreased in expression when lamin A/C itself is attacked by an EGS, but no other RNase $\mathrm{P}$ protein subunit is down-regulated. Perhaps there is a process through which the down-regulated RNase $\mathrm{P}$ protein subunits inhibit certain genes transcribed by RNA polymerase II, including lamin $\mathrm{A} / \mathrm{C}$, but these latter proteins have no effect on pol II.

The function of one of the RNase $\mathrm{P}$ protein subunits, Rpp40, which was not down-regulated by attacking Rpp38 with an EGS, was also checked in transient transfection experiments (E. Pfund and L. Yang, unpubl. experiments). Endogenous protein expressions were measured for 24 and $48 \mathrm{~h}$ after transfection with control pmU6 and pmU6$\mathrm{EGS}^{135}$ or pmU6-EGS ${ }^{230}$ (Rpp40). Compared with control cells, which were transfected with pmU6, newly made $\mathrm{EGS}^{135}$ and $\mathrm{EGS}^{230}$, which targeted Rpp40 in vitro, showed no obvious reduction on several RNase $\mathrm{P}$ protein subunits that were examined in several transient transfection experiments, including Rpp40 itself. The reason why this protein is not affected by an EGS directed against it in vivo (but does function to attack the mRNA in vitro) is not obvious. One possibility is that the nascent mRNA is immediately coated with relevant, functional proteins on transcription and is not available for interaction with an appropriate EGS or agents related to another EGS. Another explanation is that a nuclease, e.g., eri-1, is resident in the cells and will attack particular EGSs, even though the resident signal on the EGSs is not known (Kennedy et al. 2004).

These data together indicate the power of regulated promoters in a stable cell line that expresses regions at a strong level. The data also shed new light on a complex regulation process in terms of expression of RNase $\mathrm{P}$ subunits in mammalian cells.

\section{MATERIALS AND METHODS}

\section{Plasmid constructions}

The pIND vector, part of the Ecdysone-Inducible Expression Kit (Invitrogen), was modified to construct pEcU6-EGS. A fragment of the neomycin gene was replaced with one that lacked the PstI site (pIND-PstI). The MscI-NarI fragment of pEGFP-C1 (Clontech) was subcloned into pIND digested with MscI-NarI. The HSP promoter with the multiple cloning site of the pIND-PstI vector was replaced with a promoter of small nuclear U6 RNA and the multiple cloning site from the pmU6 vector (Das et al. 1988). The multiple cloning site of pmU6 was modified to add a KpnI site.
To make this pmU6+KpnI construct, oligonucleotides $5^{\prime}$-AGCT TATCGA TCTCGAGGGTACCGGGCC- $3^{\prime}$ and $5^{\prime}$-CGGTACCCTC GAGATCGATA- $3^{\prime}$ were annealed and ligated into pmU6 that was digested with HindIII and ApaI. pIND lacking a Pst site (pINDPstI) was the backbone for the final pEcU6-EGS vector. The ecdysone regulation elements containing a fragment from pIND, digested with BglI-SmaI, and U6 containing a fragment from pmU6+KpnI, digested with NotI and followed by treatment with Klenow enzyme and then digested with ApaI, were ligated into pIND-PstI and digested with BglI-ApaI.

To construct the vector that produced EGS against Rpp38 $\left(\mathrm{EGS}^{\mathrm{Rpp} 38}\right)$ and the control EGS with an inversion in the T-loop (EGS ${ }^{\text {Rpp38}}$-TL) (Plehn-Dujowich and Altman 1998), pmU6$\mathrm{EGS}^{\mathrm{Rpp} 38}$ and pmU6-EGS ${ }^{\mathrm{Rpp} 38}$-TL5) were digested with PstI and KpnI and ligated into pEcU6-EGS.

In preparation for the design of an EGS targeted to lamin $\mathrm{A} / \mathrm{C}$ mRNA, a DNA fragment that contains partial lamin DNA sequence was obtained by PCR using HeLa cell genomic DNA as a template. Primer oligonucleotides were Lamin F $5^{\prime}$-ATGGAGAC CCCGTCCCAG- $3^{\prime}$ and Lamin R $5^{\prime}$-AGGCGGCCTTGATACCGG$3^{\prime}$. The PCR fragment was cloned into pBT7 digested with StuI under the control of the T7 promoter.

Two EGSs (EGS ${ }^{114}$ and EGS ${ }^{144}$ ) against lamin A/C expression were designed by using the general methods as reported (GuerrierTakada and Altman 1999). Partial RNase T1 digestion of part lamin A/C mRNA yielded several cleavage sites, and two were chosen for EGS-directed RNase P cleavage sites.

Both 3/4 EGS lamin $^{\text {EGS }}{ }^{114}$ and $\mathrm{EGS}^{144}$ ) were individually obtained by PCR using pUC19TyrT DNA plasmid containing the gene for ptRNA ${ }^{\mathrm{Tyr}}$ from Escherichia coli as a template with primer oligonucleotide sets G114F 5'-TAATACGACTCACTATAGGCTG CAGTGCAGCAGACTCTAAATC-3'/G114R 5'-GGTACCTTTAAA AATGGTGGAGGACGAAGGATTCGAACC- $3^{\prime}$ or G144F $5^{\prime}$-TAA TACGACTCACTATAGGCTGCAGATGAGCAGACTCTAAATC3'/G144R 5'-GGTACCTTTAAAAATGGTGGCGGTCGAAGGATT CGAACC- ${ }^{\prime}$, and individually cloned into pUC19 digested with SmaI under T7 promoters for transcription in vitro (GuerrierTakada and Altman 1999). The two 3/4 EGS ${ }^{\text {lamin }}$ fragments were also digested with PstI and KpnI, and individually subcloned into pmU6 (kindly provided by R. Reddy, Baylor College of Medicine) to make pmU6-EGS114 or pmU6-EGS144 for experiments in vivo. EGS ${ }^{144}$ was also digested with PstI and KpnI, and subcloned into pEcU6 (modified in this lab to make pEcU6-EGS144 for ecdysone-inducible expression of EGS144 in EcR293 cells (Invitrogen).

Every plasmid was confirmed by restriction enzyme digestion and by DNA sequencing. DNA sequencing was performed by the Sanger method according to the protocol described by the USB Corporation Sequencing Kit.

\section{Cell line generation}

EcR 293 (Invitrogen) cells were maintained in a 5\% $\mathrm{CO}_{2}$ atmosphere at $37^{\circ} \mathrm{C}$ in minimal essential medium (MEM) containing Earle's salts and L-glutamine (GIBCO-BRL) and supplemented with $10 \%$ fetal bovine serum (Hyclone), $250 \mathrm{U} / \mathrm{mL}$ penicillin and $250 \mu \mathrm{g} / \mathrm{mL}$ streptomycin (GIBCO-BRL). EcR 293 was zeocin resistant. All transfections were made using Lipofectamin-2000 (Invitrogen). To generate a stable cell line that conditionally 
expresses an EGS, the EcR 293 primary cell line (Invitrogen), that stably expresses the heterodimeric ecdysone receptor subunits, were transfected with $10 \mu \mathrm{g}$ of EcRU6-EGS ${ }^{\mathrm{Rpp} 38}$ or EGS ${ }^{\mathrm{Rpp} 38}-\mathrm{TL}$ plasmids separately, which harbor the neomycin resistance gene. Transfected cells were recovered after $24 \mathrm{~h}$ and selected for resistance to $500 \mu \mathrm{g} / \mathrm{m} 3$ Geneticin (GIBCO) for $20 \mathrm{~d}$. Thirty individual colonies were screened for the presence of $\mathrm{EGS}^{\mathrm{Rpp} 38}$ and $\mathrm{EGS}^{\mathrm{Rpp} 38}$-TL in genomic DNA.

For stable cell line selection, EcR 293 cells (Invitrogen), derivatives of HEK 293, were plated at a 1:10 or higher dilution into fresh growth medium with relative concentration of selective drug (Geneticin, GIBCO). A similar strategy to the one described above was used to select for cells that stably expressed EGSs against lamin A/C. Expression of EGS ${ }^{144}$ (lamin A/C) in stable cells was induced by adding $5 \mu \mathrm{M}$ ponasterone A (Invitrogen) for 24 and 48 $\mathrm{h}$, according to the manufacturer's procedure.

\section{Genomic DNA analysis}

To select colonies that contain $\mathrm{EGS}^{\mathrm{Rpp} 38}$ and EGS ${ }^{\mathrm{Rpp} 38}$-TL in their genomes, total EcR 293 genomic DNA was prepared from the colonies using the Genomic-tips kit (Qiagen). PCR was carried out in the presence of $0.2 \mathrm{mM} \mathrm{dNTP}, 1.5 \mathrm{mM} \mathrm{MgCl}_{2}$, and $1 \mathrm{U}$ of Taq DNA polymerase with $500 \mathrm{ng}$ of genomic DNA and $50 \mathrm{pmol}$ of a primer pair to the neomycin gene, EGS ${ }^{\mathrm{Rpp} 38}$, and EGS ${ }^{\mathrm{Rpp} 38}-\mathrm{TL}$ in a total volume of $20 \mu \mathrm{L}$. Primer pair to the neomycin gene: $5^{\prime}-$ GAGGCTATTCGGCTATGACT- $3^{\prime}$ and $5^{\prime}$-GATCATCCTGATCG ACAAGAC- $3^{\prime}$. Primer pair to EGS $S^{\text {Rpp38 }}$ or EGS ${ }^{\text {Rpp38}}$-TL: $5^{\prime}-\mathrm{CTGC}$ AGTTCAGCAGACTCTAAATC- $3^{\prime}$ and $5^{\prime}$-GGATCCGGTACCTT TAAAAATGGTGACGTCGGAAGGATTCGAACC-3' ${ }^{\prime}$. Similar analyses were performed with EGS ${ }^{144}$.

\section{RT-PCR analysis}

Total RNA was prepared from cells using the RNeasy Mini kit (Qiagen). Total RNA $(5 \mu \mathrm{g})$ was pretreated with $6 \mathrm{U}$ of RNase-free DNase in the presence of $20 \mathrm{U}$ of RNasin and $2 \mathrm{mM} \mathrm{MgCl}_{2}$ for $1 \mathrm{~h}$ at $37^{\circ} \mathrm{C}$ in a total volume of $7 \mu \mathrm{L}$, after which, the reaction was inactivated by incubation for $5 \mathrm{~min}$ at $90^{\circ} \mathrm{C}$ and cooled on ice. cDNA synthesis was performed with $5 \mu \mathrm{g}$ of DNase-treated RNA and 300 pmol of random hexamers in the presence of $1000 \mathrm{U}$ of Superscript Reverse Transcriptase (Invitrogen) in a total volume of $60 \mu \mathrm{L}$. cDNA was purified using QIAquick PCR purification kit (Qiagen). PCR was carried out using 2 $\mu \mathrm{g}$ CDNA and 50 pmol of primer pair for Rpp38: $5^{\prime}$-TGCAGCTCCT CAAGCACC- $3^{\prime}$ and $5^{\prime}$-AACGCCAAGGCTAGAACA- $3^{\prime}$, and for actin: $5^{\prime}$-TTGACAATGGCTCCGGCAT- $3^{\prime}$ and $5^{\prime}$-CTCATTGCCAATG GTGATGA- $3^{\prime}$, in a total volume of $50 \mu \mathrm{L}$. Aliquots were removed at various time points to determine the linear range of the amplification and an optimized cycle number was selected. Subsequent PCR were amplified as follows: initial incubation at $94^{\circ} \mathrm{C}$ for $2 \mathrm{~min}$, followed by 20 cycles at $94^{\circ} \mathrm{C}$ for $30 \mathrm{sec}, 58^{\circ} \mathrm{C}$ for $1 \mathrm{~min}, 72^{\circ} \mathrm{C}$ for $30 \mathrm{sec}$.

\section{Northern analysis}

Total RNA $(10 \mu \mathrm{g})$, prepared from the cells by the SDS/phenol extraction, was loaded onto a $2.5 \%$ agarose gel. Northern hybridization was performed as described (Guerrier-Takada et al. 1995). Oligonucleotides complementary to EGS $S^{\mathrm{Rpp} 38}$ and EGS $S^{\mathrm{Rpp} 38}-\mathrm{TL}$ (5'-GACGTCGGAAGGATTCGAAGCT-3'), human nuclear mature
tRNA $^{\text {Leu }}$ and 5S rRNA (Guerrier-Takada and Altman 1999), human RNase P RNA (positions 319-340), and human RNase MRP RNA (positions 245-265) were used. All oligonucleotides were end-labeled with T4 polynucleotide kinase (New England Biolabs) and $\left[\gamma^{-}{ }^{32} \mathrm{P}\right]$ ATP (Amersham Pharmacia).

\section{Southern analysis}

Total RNA was purified with RNeasy Mini Kit (Qiagen). cDNA was reverse-transcribed from this total RNA $(10 \mu \mathrm{g})$ with random hexamer primers (Roche Applied Science) by using Superscript II reverse transcriptase (GIBCO-BRL) and was cleaned with QIAquick columns (Qiagen) before labeling with the Megaprime DNA-labeling system (Amersham Pharmacia). Labeling reaction was carried out with $0.5 \mu \mathrm{g}$ of cDNA in the presence of random nonamer primers, $\left[{ }^{32} \mathrm{P}\right] \mathrm{dCTP}$ of specific activity $6000 \mathrm{Ci} / \mathrm{mmol}$, and Klenow DNA polymerase. Labeled cDNA was heat denatured and hybridized to the membrane containing cDNA gene fragments of RNase P subunits, which were obtained by PCR from the corresponding plasmids. Quantitation of the spots on the hybridized membrane was performed by counting the hybridized spots with a Fuji PhosphorImager and adjusting the signals by using adjacent blank spots as background.

\section{Western analysis}

Cells were detached from petri dishes with trypsin-EDTA, washed with phosphate-buffered saline (PBS, $137 \mathrm{mM} \mathrm{NaCl}, 2.7 \mathrm{mM} \mathrm{KCl}$, $10 \mathrm{mM} \mathrm{Na} 2 \mathrm{HPO}_{4}, 2 \mathrm{mM} \mathrm{KH}_{2} \mathrm{PO}_{4}$ at $\mathrm{pH}$ 7.0), centrifuged, and boiled for $5 \mathrm{~min}$ in gel-loading buffer.

Samples of total protein $(10 \mu \mathrm{g})$ were separated in a $12.5 \%$ polyacrylamide/SDS gel, transferred to a nitrocellulose membrane (Schleicher \& Schuell), and incubated with antibodies against RNase P subunits as described (Jiang and Altman 2001). The concentration of total protein amount in the extracts used was measured by the Bradford assay (Bradford 1976; Eder et al. 1997).

\section{RNase $\mathbf{P}$ activity assay}

Reactions $(10 \mu \mathrm{L})$ contained $10 \mathrm{mM}$ Tris- $\mathrm{HCl}(\mathrm{pH} 7.8), 10 \mathrm{mM}$ $\mathrm{MgCl}_{2}, 200 \mathrm{mM} \mathrm{KCl}, 1 \mathrm{mM}$ DTT, 1 pmol precursor tRNA substrate, radiolabeled to a specific activity of $100 \mathrm{cpm} / \mathrm{pmol}$, and 1 $\mu \mathrm{L}$ of crude RNase P as part of a S16 cell extract. The substrate, the precursor to the suppressor tRNA ${ }^{\text {Ser }}$, supS1, from Schizosaccharomyces pombe (Drainas and Zimmerly 1989), was transcribed in the presence of $\left[\alpha-{ }^{32} \mathrm{P}\right] \mathrm{GTP}$. Assays were performed as described (Jiang and Altman 2001). Reaction products were detected and quantified using PhosphorImager software.

\section{RNase T1 digestion and alkali ladder}

Partial RNase T1 digestion ( $20 \mu \mathrm{L}$ reaction) was performed in PA buffer $\left(50 \mathrm{mM}\right.$ Tris. Hcl at $\mathrm{pH} 7.5,10 \mathrm{mM} \mathrm{MgCl}_{2}, 100 \mathrm{mM}$ $\left.\mathrm{NH}_{4} \mathrm{Cl}\right)$ with the $5^{\prime}$-end radiolabeled RNA $(50,000 \mathrm{cpm})$ and 1 $\mu \mathrm{L}$ RNase T1 $(50 \mathrm{U} / \mathrm{mL})$. After a 20 -sec incubation at $0^{\circ} \mathrm{C}$, phenol $(2 \mu \mathrm{L})$, glycogen $10 \times(2 \mu \mathrm{L})$, and ethanol $95 \%(60 \mu \mathrm{L})$ were added and the mixture was kept overnight at $-20^{\circ} \mathrm{C}$.

Alkali ladder reactions ( $50 \mu \mathrm{L}$ reaction) were carried out with $50,000 \mathrm{cpm}$-labeled RNA in $50 \mathrm{mM}$ sodium carbonate ( $\mathrm{pH} 9.2$ ), 
and $1 \mathrm{mM}$ EDTA for $3 \mathrm{~min}$ at $95^{\circ} \mathrm{C}$ and then followed by ethanol precipitation. After centrifugation and ethanol wash, the obtained pellets were dried, dissolved in urea dye, boiled and then loaded onto $12 \%$ and $8 \%$ polyacrylamide/7M urea gels.

\section{ACKNOWLEDGMENTS}

We are grateful to our colleagues, especially Dr. Cecilia GuerrierTakada, for helpful discussions. This research was supported by a grant from the NIH (GM 19422) to S.A. and by assistance from Yale University. L.Y. was supported by a Focused Giving grant from the Johnson \& Johnson Co.

Received June 17, 2005; accepted July 14, 2005.

\section{REFERENCES}

Bradford, M.M. 1976. A rapid and sensitive method for the quantitation of microgram quantities of protein utilizing the principle of protein-dye binding. Anal. Biochem. 7: 248-254.

Das, G., Henning, D., Wright, D., and Reddy, R. 1988. Upstream regulatory elements are necessary and sufficient for transcription of a U6 RNA gene by RNA polymerase III. EMBO J. 7: 503-512.

Drainas, D. and Zimmerly, S. 1989. Substrate structural requirements of Schizosaccharomyces pombe RNase P. FEBS Lett. 251: 84-88.

Eder, P., Kekuda, R., Stolc, V., and Altman, S. 1997. Characterization of two scleroderma autoimmune antigens that copurify with human ribonuclease P. Proc. Natl. Acad. Sci. 94: 1101-1106.

Forster, A. and Altman, S. 1990. External guide sequences for an RNA enzyme. Science 249: 783-786.
Guerrier-Takada, C. and Altman, S. 1999. Inactivation of gene expression using ribonuclease $\mathrm{P}$ and external guide sequences. Methods Enzymol. 313: 442-456.

Guerrier-Takada, C., Li, Y., and Altman, S. 1995. Artificial regulation of gene expression in Escherichia coli by RNase P. Proc. Natl. Acad. Sci. 92: 11115-11119.

Jiang, T. and Altman, S. 2001. Protein-protein interactions with subunits of human nuclear RNase P. Proc. Natl. Acad. Sci. 98: 920-925.

Kennedy, S., Wang, D., and Ruvkun, G. 2004. A conserved siRNAdegrading RNase negatively regulates RNA interference in C. elegans. Nature 427: 645-649.

Kovrigina, E., Wesolowski, D., and Altman, S. 2003. Coordinate inhibition of expression of several genes for protein subunits of human nuclear RNase P. Proc. Natl. Acad. Sci. 100: 1598-1602.

No, D., Yao, T.P., and Evans, R.M. 1996. Ecdysone-inducible gene expression in mammalian cells and transgenic mice. Proc. Natl. Acad. Sci. 93: 3346-3351.

Plehn-Dujowich, D. and Altman, S. 1998. Effective inhibition of influenza virus production in cultured cells by external guide sequences and ribonuclease P. Proc. Natl. Acad. Sci. 95: 7327-7332.

Shockett, P., Difilippantonio, M., Hellman, N., and Schatz, D.G. 1995. A modified tetracycline-regulated system provides autoregulatory, inducible gene expression in cultured cells and transgenic mice. Proc. Natl. Acad. Sci . 92: 6522-6526.

Yao, T.P., Forman, B.M., Jiang, Z., Cherbas, L., Chen, J.D., McKeown, M., Cherbas, P., and Evans, R.M. 1993. Functional ecdysone receptor is the product of EcR and Ultraspiracle genes. Nature 366: 476-479.

Yuan, Y. and Altman, S. 1994. Selection of guide sequences that direct efficient cleavage of mRNA by human ribonuclease P. Science 263: $1269-1273$.

Yuan, Y., Hwang, E., and Altman, S. 1992. Targeted cleavage of mRNA by human RNase P. Proc. Natl. Acad. Sci. 89: 8006-8010. 

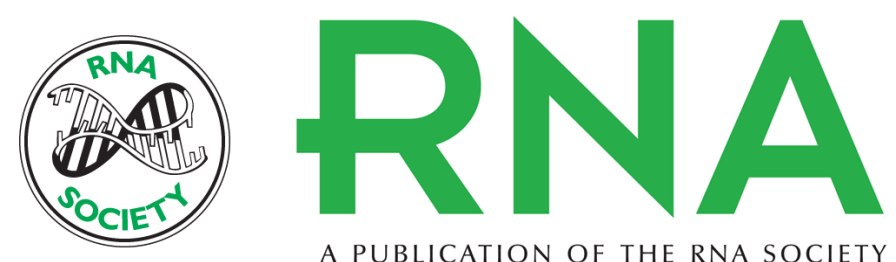

A PUBLICATION OF THE RNA SOCIETY

\section{Regulated expression of functional external guide sequences in mammalian cells using a U6 RNA polymerase III promoter}

ELIZAVETA KOVRIGINA, LI YANG, EMMANUEL PFUND, et al.

RNA 2005 11: 1588-1595

References This article cites 16 articles, 10 of which can be accessed free at:

http://rnajournal.cshlp.org/content/11/10/1588.full.html\#ref-list-1

License

Email Alerting Receive free email alerts when new articles cite this article - sign up in the box at the Service top right corner of the article or click here. 